\title{
Transferring land-use rights with transportation infrastructure extensions: Evidence on spatiotemporal price formation in Shanghai
}

\author{
Zheng Chang (corresponding author) \\ City University of Hong Kong \\ zchang@cityu.edu.hk
}

\author{
Jin Murakami \\ City University of Hong Kong \\ jin.m@cityu.edu.hk
}

Abstract: To address the efficiency and sustainability of residential suburbanization under state leasehold systems, this study examines the price formation of long-term land-use rights for general and compensational housing empirically, considering the successive expansions of new metro lines and highway networks during 2004-2016 in Shanghai-one of the world's fastest growing megacities. The results of our spatial autoregressive models infer that the accessibility benefits of metro extensions are considerably capitalized into both the ask and transaction prices of land-use rights for general housing in the suburbs, whereas those for highway construction are insignificant. A series of spatiotemporal regressions demonstrate that the premiums for proximity to new metro stations bid by private developers are much higher than those asked by local governments during pre-metro years, probably due to local governments' strategic site arrangements for transit-oriented suburbanization and/or developers' speculative land acquisitions in Shanghai's upward suburban housing market. This study further reveals that the prices of land-use rights for compensational housing do not reflect any economic externalities attributable to metro stations and highway interchanges, which might trigger the unfair redistribution of property rights, accessibility, and economic opportunities among relocated farmers around city-fringe areas.

Keywords: land-use rights; metro and highway; housing policy; price formation; suburbanization; China

\section{Article history:}

Received: December 14, 2017

Received in revised form:

July 7, 2018

Accepted: September 14, 2018

Available online: January 28,

2019

Copyright 2019 Zheng Chang \& Jin Murakami

http://dx.doi.org/10.5198/jtlu.2019.1357

ISSN: 1938-7849 | Licensed under the Creative Commons Attribution - Noncommercial License 4.0

The Journal of Transport and Land Use is the official journal of the World Society for Transport and Land Use (WSTLUR) and is published and sponsored by the University of Minnesota Center for Transportation Studies. 


\section{Introduction}

Global concerns over environmental degradation and socioeconomic disparity arising from suburban sprawl have called for empirical research and scientific evidence on transportation infrastructure investment, metropolitan-scale land management, and subsequent human landscape across regions (UNHabitat, 2011). Intergovernmental scholars acknowledge that the 21 st century's global population growth will take place mostly around city fringes in developing countries, and the greatest policy challenges for environmental mitigation and socioeconomic inclusion would appear in rapidly expanding areas, where urban transportation infrastructure and human settlement patterns are not yet locked in (Seto et al., 2014). Regarding policy approaches, a good combination of transit-supportive spatial strategies and market initiatives is expected to alter the pace and shape of suburbanization along a sustainable pathway, particularly in emerging economies.

From this global perspective, the experiences of fast growing cities in China have gained special attention over the past two decades (e.g., Gaubatz, 1999; Ma, Lu, \& Sun, 2008; Wang, Kundu, \& Chen, 2010; Zhou \& Ma, 2000). One critical viewpoint associated with Chinese cities' suburbanization is on the high rates of motorization. As a consequence of the open-door policy and rising household income, both private vehicle ownership and vehicle-kilometers traveled continue to grow considerably along with the consecutive extensions of radial and ring highway networks with the scope of inducing mobility in China's city-fringe markets (Gakenheimer, 1999; Kenworthy \& Hu, 2002; Kenworthy \& Townsend, 2002; Shen, 1997; Zhao, 2010; Zhao, Lü, \& de Roo, 2010). However, car-dependent suburbanization has been widely recognized as a major driver of severe traffic congestion, air pollution, noise, wasteful energy use, greenhouse gas emissions, and social inequality regarding accessibility across the growing metropolitan areas in China (Pucher, Peng, Mittal, Zhu, \& Korattyswaroopam, 2007; Martin, 2007; Yan \& Crookes, 2010).

In response to these looming environmental and socioeconomic threats, Chinese cities' policy paradigms have progressively been shifting from mobility-induced engineering to accessibility-enhanced planning. In recent metropolitan-wide spatial strategies, effective integration of land use and public transportation or transit-oriented development (TOD) is noticeably encouraged as an alternative form of sustainable suburbanization (Cervero, 2013; Lyu, Bertolini, \& Pfeffer, 2016; Pan, Shen, \& Liu, 2011; Suzuki, Cervero, \& Iuchi, 2013). In fact, high-density housing developments with small-size blocks and well-connected street networks around transit stations are estimated to curb suburban households' car ownership rates and motorized travel footprints via enhanced accessibility in large metropolitan areas, such as Shanghai (Cervero \& Day, 2008; Day \& Cervero, 2010; Pan, Shen, \& Zhang, 2009).

Essentially, the Chinese version of TOD has been adopted along with new metro transit systems (Zhang, 2007). Over the past 15 years, major coastal and inland cities have successively delivered largescale metro projects using public-private partnership schemes not only to mitigate the environmental impacts of suburban sprawl, but also to generate wider economic benefits or land productivity gains through metropolitan-wide accessibility improvements (Chang, 2013; Chang \& Phang, 2017; Loo \& $\mathrm{Li}$, 2006; Shen, Jiao, He, \& Li, 2015). Nevertheless, facing greater funding gaps, capital-intensive metro extension practices have increasingly tapped into municipal revenues from sales of long-term land-use rights under China's municipal leasehold system, the financial sustainability becoming more susceptive to the profitability and volatility of real estate markets (Chang, 2014, Suzuki, Murakami, Hong, \& Tamayose, 2015).

In search of sustainable suburbanization and infrastructure finance, a growing body of empirical research analyzes the impacts of metro investments on residential property markets based on the bid-rent theory advanced by Alonso (1964), Muth (1964), and Mills (1972). Various hedonic price studies have 
been conducted to measure metro accessibility benefits from private housing sales or rents in Beijing (Xu, Zhang, \& Aditjandra, 2016; Zhang, Meng, Wang, \& Xu, 2014; Zhang \& Wang, 2013; Zheng \& Kahn, 2008), Shanghai (Pan \& Zhang, 2008; Wang, Feng, Deng, \& Cheng, 2016), Guanzhou (Tian, 2006), and Wuhan (Huang \& Yin, 2015; Xu \& Zhang, 2016). The market capitalization effects estimated across these major cities are positive if accompanied by transit-supportive land-use coordination in a specific radius from metro stations. Housing price analyses reveal some end consumers' transitoriented living preferences for short- or mid-term tenancies on the housing market, but little is known about intermediate transactions for long-term land-use rights under China's municipal leasehold system (Yang, Chen, Le, \& Zhang, 2016).

The leasehold administration for land-use control and local public finance over the past two decades has been challenged as a serious cause of suburban sprawl, land speculation, and housing unaffordability in China's large metropolitan areas (Man, 2012; Xie, Parsa, \& Redding, 2002; Zhang, 2000; Zhu, 2002). Particularly, de facto landowners (e.g., state-owned enterprises, danwei, collectives, and military agencies) transferred land-use rights to private developers unofficially, which led to inefficient land supply and ad hoc property development. Additionally, city-state agencies set low compensation prices for farmland requisition without any clear standards, and converted countryside excessively into residential and industrial areas (Ding, 2007; Han, 2000; Lichtenberg \& Ding, 2008). In a series of policy reforms, the establishment of land banking systems since the late 1990s has consolidated the local regulatory power to control the transfer of land-use rights for accountable and sustainable resource allocations, whereas housing affordability and the fair redistribution of property rights for landless farmers have remained important socioeconomic considerations (Ding, 2003; He, Liu, Webster, \& Wu, 2009; Tian \& Ma, 2009; Xu, Yeh, \& Wu, 2009; Zhang, 2012).

Nevertheless, there is a paucity of empirical research on the nexus between land leasehold administration and transportation infrastructure investment as a critical path toward sustainable suburbanization in China (Yang et al., 2016; Yang, Quan, Yan, \& He, 2016). This paper contributes to limited literature by providing new spatiotemporal evidence on transportation and land-use coordination under public leasehold in several distinctive ways. First, it empirically analyzes parcel-level transaction records for long-term land-use rights within the Shanghai metropolitan area during the growth period of 2004 2016. Second, the land transaction analysis estimates the price formation of long-term land-use rights spatiotemporally attributable to the successive extensions of both metro and highway networks along with other local public goods. Third, the price premiums (or discounts) for proximity to new metro stations and highway entrances asked by district governments (as initial land suppliers) and bid by developers (as intermediate land consumers and property suppliers) are respectively scrutinized. Finally, two categories of residential land transactions - general and compensational housing - are distinguished to better understand the market efficiency and social inequity brought by car-dependent sprawl and/or transit-oriented suburbanization.

The remainder of this paper is organized as follows. Section 2 describes the background of Shanghai, with respect to its spatial transformation, transportation investment, and land administration characteristics. Section 3 presents the datasets used to analyze the case of Shanghai. After the methodology and regression results are presented in Section 4, conclusive empirical findings, policy implications, and analytical challenges are discussed in Section 5.

\section{The Shanghai case}

Shanghai has one of the world's most populous administrative areas, being home to around 24 million inhabitants in a total area of $6,340 \mathrm{~km}^{2}$. According to the 2014 Revision of World Urbanization Prospects (United Nations, 2014), the megacity has grown by absorbing nearly 10 million people over 
the last two decades and is projected to attain approximately 7 million more residents by 2030 , thus putting more pressure on housing development and residential suburbanization across its jurisdictional territories. By general definition, Shanghai's administrative boundary consists of seven urban and nine suburban districts, including Chongming district's three islands. District governments arrange detailed development plans and implement land leasing programs, whereas Shanghai's municipal government rules a territory-wide masterplan and provides major infrastructure and services, such as metro, roads, green spaces, schools, and healthcare systems.

Over the past two decades, Shanghai's motorization has grown to a relatively moderate degree, partly due to the effectiveness of its vehicle ownership control (Chen \& Zhao, 2013). However, regarding infrastructure, highway constructions continued to grow at a fast pace until 2007, the total network length reaching $825 \mathrm{~km}$ by 2015 (Shanghai Statistical Bureau, 2016). In addition to such massive automobility provisions, public transportation infrastructure and services, especially metro networks, have progressively been promoted as modal alternatives for environmental sustainability and economic progress. Around the early 2000, Shanghai operated four metro lines with a total length of $62.9 \mathrm{~km}$. By the end of 2016, the city had China's largest metro system with 13 lines in operation and a total length of $617.5 \mathrm{~km}$, thus catching up with the multiple radial and ring highway network. Remarkably, five more metro lines are under construction, with a plan to cover Shanghai's densely urbanized and rapidly suburbanizing territories with a network of $1,000 \mathrm{~km}$ and to be operational by 2020. These metropolitanwide metro extensions are expected to not merely meet mounting mobility needs, but rather prevent wasteful sprawling along with the adoption of transit-oriented land-use principles around the city-fringe districts of Shanghai (Pan et al., 2011; Pan \& Zhang, 2008).

Given the importance of leasehold administration in land management and municipal finance, Shanghai established China's first land banking system in 1996, one of the most successful local finance models among major Chinese cities. Indeed, the municipal government saved fiscal reliance on the sales of land-use rights by an average of $22.3 \%$ of its total revenue for $2004-2016,{ }^{1}$ even when significant capital was needed to deliver a series of metro projects across urban and suburban districts. Furthermore, according to our preliminary interviews with local planning officials, Shanghai's land leasing program is implemented at the district government level and the revenues generated from transactions for longterm land-use rights are shared between each district and the municipal government, usually at a ratio of eight to two. In other words, Shanghai's leasehold administration practices have been weakly linked to the municipal government's infrastructure financing motives.

Using the majority of Shanghai's leasehold revenues, district governments have been increasingly required to carry out land requisition and compensation tasks in cases of rapid suburbanization. To improve the fairness of land requisition, a market-based valuation mechanism has been encouraged through multiple compensation methods (Shanghai Municipal People's Government, 2009). In Shanghai, the provision of compensational housing has been largely implemented through district governments' land leasing programs since 2010. Typically, state-owned enterprises (SOEs) and private developers are invited to tender for the construction of compact and affordable compensational housing units within relocated farmers' original districts, which cannot be resold within three years and are used as mortgage collateral (Shanghai Municipal People's Government, 2011). After construction, the district governments repurchase land-use rights for compensational housing and transfer new housing units to farmers. Developers generally obtain about $10 \%$ net profit from compensational housing projects, although the district governments' repurchase prices vary by project. This in-kind compensation exercise, accompanied by general housing development and major transportation investment, reconfigured human settlement patterns noticeably and characterizes socioeconomic alterations across Shanghai's citycenter and city-fringe jurisdictions.

${ }^{1}$ We compute the proportion of land leasing income in Shanghai's total revenue. The annual land leasing revenue is calculated based on the transaction records of all land parcels from 2004 to 2016, as extracted from the official website of Shanghai's Land Resources and Planning Bureau at http://www.shgtj.gov.cn/. 


\section{Data organization}

The datasets to analyze the case of Shanghai have largely three attributes: residential land transactions; major transportation infrastructure; and other local public goods. First, parcel-level data on all land transaction records for housing development in Shanghai (except Chongming County) during 20042016 are extracted from the Shanghai Land Resource and Planning Bureau's website (www.shgtj.gov. $\mathrm{cn})$. Each transaction record includes detailed information on street-level address, site area, permitted floor area ratio (FAR), land-use type, ask price, transaction price, transaction date, auction type (auction or listing), and buyer identity (names of successful bidders). After excluding 83 unsuccessful transaction cases, 1,088 transacted land parcels are used for our empirical analyses.

Second, to control for inflation, both ask and transaction prices for 2004-2015 are adjusted by the consumer price index for 2016. More importantly, the final prices bid by developers (as intermediate land consumers and property suppliers), which consider market returns and project risks, are noticeably different from the initial prices asked by the governments (as land suppliers), which account for firm asset valuation or formula. Hence, the "bid-ask spread" - the transaction price divided by the ask price-is calculated to determine the government's assessment and market profitability (or market speculativeness) of long-term land-use rights under various locational and temporal conditions.

Based on land-use types, land transactions were originally classified into three housing categories: single-use residential, mixed-use residential, and compensational (called Huiqian House). However, since the fundamental characteristics of land transactions for single- and mixed-use housing were found to be almost identical in our preliminary analyses, we combine these two types into one "general" group. As such, two categories of residential land transactions-general housing and compensational housing - are respectively analyzed. In Shanghai, almost all land parcels are leased through listing (called "two-stage auction") and less than 5\% of them are transacted trough tendering (called "sealed bid"). ${ }^{2}$ No land parcels are leased out through regular "English auction" processes in Shanghai, although this is widely used in other Chinese cities. By identifying the names of successful bidders, we find that around $27 \%$ of the residential land parcels are leased out to SOEs.

From the recorded street-level addresses, we geocode all transacted residential land parcels using a geographic information system (GIS). Figure 1 shows the spatial distribution of land transactions for both general and compensation housing. Note that $88.7 \%$ of the land parcels for general housing and $92.7 \%$ of those for compensational housing were the suburban districts over the past decade. The GIS data on residential land transactions for general and compensational housing are spatiotemporally related to those on major transportation infrastructure-metro stations and highway interchanges - that were geocoded from the locations of metro stations and highway entrances found on Shanghai's government website, ${ }^{3}$ as shown in Figure 2. Specifically, straight distances to the closest metro station or highway interchange (spatial) and year differences between transaction and infrastructure opening dates (temporal) are computed for each land parcel. The proportion of residential land transactions within 1 $\mathrm{km}$ of both existing and future (within four years) metro stations is $26.0 \%$ for general and $16.8 \%$ for compensational housing.

${ }^{2}$ Land prices through tending are typically lower than those through listing and English auction. For tending, local governments determine the winners largely based on bidders' credibility and social responsibility rather than the amount bid. Cai, Henderson, and Zhang (2013) provide detailed explanations for different auction modes.

${ }^{3}$ The metro stops can be found on Shanghai metro website at http://service.shmetro.com/en/. Details on highway entrances can be found through Shanghai's government data service at http://www.datashanghai.gov.cn/home 


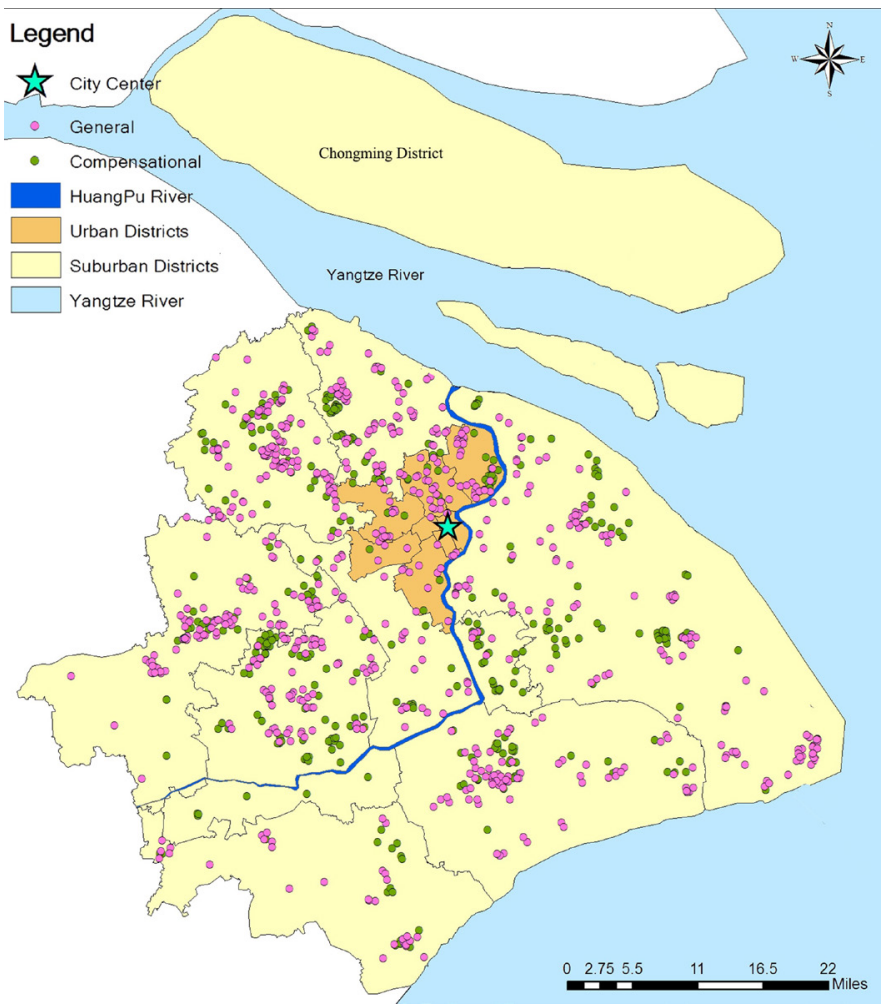

Figure 1. Spatial distribution of land transactions for housing development in Shanghai, 2004-2016

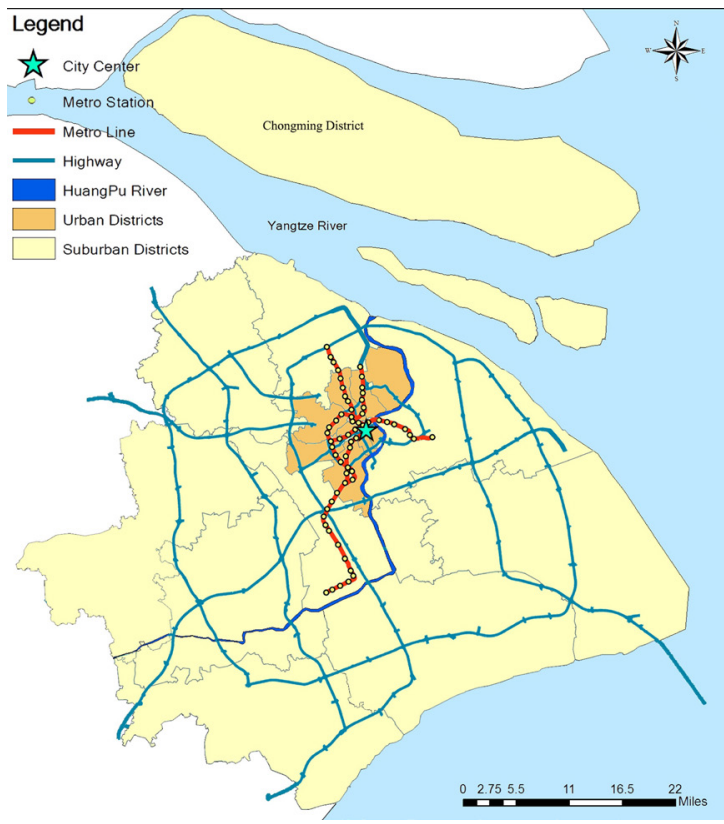

(a) 2004

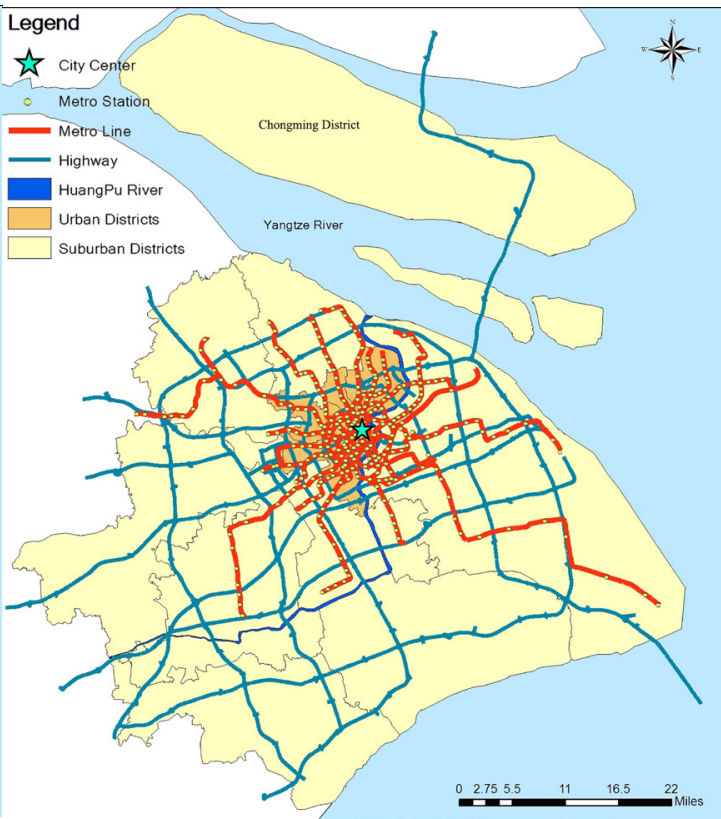

(b) 2016

Figure 2. Transportation infrastructure extensions, 2004-2016 
Similarly, a range of local public goods are geocoded and spatially associated with GIS data for all residential land transactions in Shanghai. The office addresses of the city and 19 (former) district governments are used to denote the city center (mono-centricity) and sub-centers (poly-centricity), as those old jurisdictions predetermined Shanghai's fundamental spatial structure with their provision of basic public services over the past decades. ${ }^{4}$ Each district contains a dozen of Jiedaos and towns, Shanghai's smallest administrative units. By combining adjacent Jiedaos and towns with similar population density, we distinguish 59 zones (seven zones in the urban areas and 52 zones in the suburban areas) ${ }^{5}$ to control for unobservable sub-district effects. We also identify urban parks and universities as countable local public goods to be considered in analyzing residential land transactions. Note that, in Shanghai, these features existed before the land transaction period (2004-2016). Therefore, the straight distances from land to local public goods are regarded as static variables, while those from land to the closest metro stations and highway entrances are treated as dynamic variables. Table 1 summarizes all variables organized for the two types of residential land, respectively.

Table 1. Variable definitions and summary statistics

\begin{tabular}{|c|c|c|c|c|c|c|c|}
\hline \multirow[t]{2}{*}{ Variable } & \multirow[t]{2}{*}{ Description } & \multicolumn{3}{|c|}{$\begin{array}{l}\text { Land for general housing } \\
(2004-2016)\end{array}$} & \multicolumn{3}{|c|}{$\begin{array}{l}\text { Land for compensational housing } \\
(2010-2016)\end{array}$} \\
\hline & & Observation & Mean & SD & Observation & Mean & SD \\
\hline \multicolumn{8}{|l|}{ Dependent } \\
\hline Land_TP & Transaction price of a land parcel (CNY per square meter) & 707 & 21519.17 & 28990.43 & 381 & 6567.03 & 8781.92 \\
\hline Land_AskP & Ask price of a land parcel (CNY per square meter) & 660 & 14341.38 & 18997.64 & 376 & 6629.8 & 8820.93 \\
\hline Bid-Ask Spread & Defined by the transaction price divided by ask price & 660 & 1.7048 & 0.8319 & 376 & 1 & 0 \\
\hline \multicolumn{8}{|l|}{ Attributes } \\
\hline Urban & Binary, 1 = land transaction in urban districts, $0=$ otherwise & 707 & 0.1132 & 0.317 & 381 & 0.0735 & 0.2613 \\
\hline L_Size & Size of land parcels, in meter 2 & 707 & 68825.64 & 54596.91 & 381 & 54151.81 & 34033.35 \\
\hline FAR & Permitted FAR for each land parcel & 707 & 1.7899 & 0.6844 & 381 & 1.8633 & 0.4 \\
\hline SOE & Binary, $1=$ land purchased by a SOE developer, $0=$ otherwise & 707 & 0.2631 & 0.4406 & 381 & 0.273 & 0.4461 \\
\hline Tendering & $\begin{array}{l}\text { Binary, } 1=\text { the auction type of the land parcel is tendering, } 0 \\
=\text { otherwise }\end{array}$ & 707 & 0.0693 & 0.2542 & 381 & 0.0052 & 0.0724 \\
\hline \multicolumn{8}{|c|}{ Location \& Access } \\
\hline C_Center & $\begin{array}{l}\text { Distance of a land parcel to city center, in meter, static vari- } \\
\text { able }\end{array}$ & 707 & 29553.54 & 13528.53 & 381 & 28727.72 & 11685.77 \\
\hline D_Center & $\begin{array}{l}\text { Distance of a land parcel to its corresponding district center, } \\
\text { in meter, static variable }\end{array}$ & 707 & 9044.102 & 6732.96 & 381 & 9753.87 & 5886.71 \\
\hline Uni & $\begin{array}{l}\text { Distance of a land parcel to the closest university, in meter, } \\
\text { static variable }\end{array}$ & 707 & 6688.52 & 4635.9 & 381 & 7047.61 & 4209.91 \\
\hline Park & $\begin{array}{l}\text { Distance of a land parcel to the closest public park, in meter, } \\
\text { static variable }\end{array}$ & 707 & 5306.74 & 3177.62 & 381 & 5950.47 & 3824.65 \\
\hline HighW & $\begin{array}{l}\text { Distance of a land parcel to the closest highway entrances, in } \\
\text { meter, dynamic variable }\end{array}$ & 707 & 2247.8 & 1746.57 & 381 & 2502.4 & 1507.9 \\
\hline Metro & $\begin{array}{l}\text { Distance of a land parcel to the closest metro stop, in meter, } \\
\text { dynamic variable }\end{array}$ & 707 & 7990.17 & 8989.68 & 381 & 5792.6 & 5965.02 \\
\hline
\end{tabular}

\footnotetext{
${ }^{4}$ From 2009 to 2015, three districts were merged. Therefore, there were 16 districts in Shanghai as of 2016.

${ }^{5}$ In urban areas, each district is regarded as a zone. In suburban areas, the size of zones ranges from $50 \mathrm{~km}^{2}$ to $150 \mathrm{~km}^{2}$.
} 
Year lead/Lag time

effect

\begin{tabular}{|c|c|c|c|c|c|c|c|}
\hline D_MLead4 & $\begin{array}{l}\text { Binary, } 1 \text { = a land parcel located within } 1 \mathrm{~km} \text { of metro station } \\
\text { four years ago, } 0=\text { otherwise }\end{array}$ & 707 & 0.0693 & 0.2542 & 381 & 0.0367 & 0.1884 \\
\hline D_MLead3 & $\begin{array}{l}\text { Binary, } 1 \text { = a land parcel located within } 1 \mathrm{~km} \text { of metro station } \\
\text { three years ago, } 0=\text { otherwise }\end{array}$ & 707 & 0.0905 & 0.2871 & 381 & 0.0735 & 0.2613 \\
\hline D_MLead2 & $\begin{array}{l}\text { Binary, } 1=\mathrm{a} \text { land parcel located within } 1 \mathrm{~km} \text { of metro station } \\
\text { two years ago, } 0=\text { otherwise }\end{array}$ & 707 & 0.1188 & 0.3238 & 381 & 0.0919 & 0.2892 \\
\hline D_MLead1 & $\begin{array}{l}\text { Binary, } 1=\text { a land parcel located within } 1 \mathrm{~km} \text { of metro station } \\
\text { one year ago, } 0=\text { otherwise }\end{array}$ & 707 & 0.133 & 0.3398 & 381 & 0.1102 & 0.3136 \\
\hline D_Metro & $\begin{array}{l}\text { Binary, } 1 \text { = a land parcel located within } 1 \mathrm{~km} \text { of metro station } \\
\text { in the same year, } 0=\text { otherwise }\end{array}$ & 707 & 0.1542 & 0.3614 & 381 & 0.1365 & 0.3438 \\
\hline D_MLag1 & $\begin{array}{l}\text { Binary, } 1 \text { = a land parcel located within } 1 \mathrm{~km} \text { of metro station } \\
\text { one year later, } 0=\text { otherwise }\end{array}$ & 707 & 0.1825 & 0.3865 & 381 & 0.1496 & 0.3572 \\
\hline D_MLag2 & $\begin{array}{l}\text { Binary, } 1 \text { = a land parcel located within } 1 \mathrm{~km} \text { of metro station } \\
\text { two years later, } 0=\text { otherwise }\end{array}$ & 707 & 0.2192 & 0.414 & 381 & 0.1575 & 0.3647 \\
\hline D_MLag3 & $\begin{array}{l}\text { Binary, } 1 \text { = a land parcel located within } 1 \mathrm{~km} \text { of metro station } \\
\text { three years later, } 0=\text { otherwise }\end{array}$ & 707 & 0.2433 & 0.4294 & 381 & 0.1654 & 0.372 \\
\hline D_MLag4 & $\begin{array}{l}\text { Binary, } 1 \text { = a land parcel located within } 1 \mathrm{~km} \text { of metro station } \\
\text { four years later, } 0=\text { otherwise }\end{array}$ & 707 & 0.2603 & 0.4391 & 381 & 0.168 & 0.3743 \\
\hline
\end{tabular}

Notes: SD refers to standard deviation.

\section{$4 \quad$ Empirical analysis}

This study assesses whether Shanghai's land price formation for housing provisions (or residential suburbanization process) is spatiotemporally associated with the extensions of major transportation infrastructure along either transit-oriented and/or car-dependent pathways by analyzing the intermediate transfers of long-term land-use rights from the district governments to housing developers in three sets of regressions for: (1) transaction prices; (2) ask prices and bid-ask spreads; and (3) transaction prices, ask prices, and bid-ask spreads with time effects. Major transportation investments are expected to reduce commuting costs and affect housing prices via accessibility improvements as well as amenity influences (e.g., traffic congestion, noise, and air pollution). Numerous studies typically estimate such capitalization effects in end-consumer markets - housing sales or rents under freehold systems - using hedonic price methods based on the assumptions of utility theory (Rosen, 1974). We assume that similar price regressions could be applied to measure the valuation of dynamic metro extensions and highway construction on the intermediate land markets for housing development under Shanghai's leasehold system, wherein a sufficiently large number of initial land suppliers (district governments) and intermediate land consumers (housing developers) determine rational prices for major transportation infrastructure and other local public goods through local competition for long-term land-use rights (Tiebout, 1956; Wilson \& Wildasin, 2004). Subsequently, developers acting as housing suppliers are likely to transfer these land prices (or land acquisition costs) to end-consumer markets through property sales or rents for the following years. From these theoretical and pragmatic understandings, Equation (1) is specified for the three kinds of land price regressions:

$$
P_{i j t}=\alpha_{0}+\alpha_{1} L C_{i j t}+\alpha_{2} P G_{i j}+\alpha_{3} T F_{i j t}+\eta_{j}+y_{\mathrm{t}}+\varepsilon_{\mathrm{ijt}}
$$


where $P_{i j t}$ is a vector of the price of land parcel $i$ in zone $j$ and year $t, L C_{i j t}$ is a vector of the lease condition attributes (site area, FAR, auction type, and SOE dummy), $P G_{i j}$ is a vector of the distance to local public goods (city center, district centers, universities, and large parks), $T F_{i j t}$ is a vector of the distance to the closest major transportation facilities (metro station and highway interchange), $\eta_{j}$ is a set of zone dummies to control for spatial heterogeneity among sub-districts, $y_{t}$ is a set of year dummies to control for unobservable time effects, $\varepsilon_{i j t}$ is a general error term, $\alpha_{0}$ is a constant, and $\alpha_{1}, \alpha_{2}$, and $\alpha_{3}$ are vectors of the coefficients of independent variables to be estimated. Note that our analysis applies fulllog regressions to improve model fitness, lessen the effects of heteroscedasticity, and discuss estimated coefficients as elasticities.

It is likely that the prices of land parcels revealed by governments and developers within a certain micro-geographic unit (e.g., neighborhood, residential community, or transportation catchment area) are mutually affected with each other - "spatial dependency" and/or the prices of land parcels revealed by governments and developers reflect the value of unobservable local attributes within the certain spatial unit - "spatial heterogeneity", when transaction records are publicly open to both initial suppliers (governments) and intermediate consumers (developers). Indeed, detecting the presence of microgeographic data clustering among land transactions in Shanghai, we anticipate that the ordinary least squares (OLS) estimator would produce biased results. To overcome the problem of neighborhood-scale spatial dependency and/or heterogeneity, we apply spatial autoregressive models (Drukker, Prucha, \& Raciborski, 2011) as shown in Equations (2) and (3):

$$
\begin{aligned}
& P_{i j t}=\alpha_{0}+\alpha_{1} L C_{i j t}+\alpha_{2} P G_{i j}+\alpha_{3} T F_{i j t}+\lambda W P_{i j t}+\eta_{j}+y_{t}+\varepsilon_{i j t} \\
& \varepsilon_{i j t}=\rho W \varepsilon_{i j t}+\mu_{i j t}
\end{aligned}
$$

where $W$ is the spatial weight matrix (using the inverse distance between land parcels within $3 \mathrm{~km}$ ) and $\lambda$ and $\rho$ are the parameters for spatial lag and error terms, respectively. Moran's I statistics indicate that there is significant data clustering among land transactions for both general and compensational housing. After testing the spatial lag model (SLM), spatial error model (SEM), and general spatial model (GSM), we identify that SLM outperforms SEM and GSM based on the Lagrange multiplier (LM) test for robustness along with the Akaike information criterion (AIC) and Bayesian information criterion (BIC) for fitness, although differences in coefficients among the three models appear minor. The specification of micro-geographic units for the spatial dependency of parcel-level land-use rights is essentially heuristic by testing a spectrum of distance-based spatial weight matrixes from 200 meters to 1600 meters for general housing and compensational housing, respectively, as the average scale of individual superblock neighborhood, agricultural community, or transportation catchment area within Shanghai's urban and suburban zones can be identified in this distance range. The SLM results indicate that the spatial correlation is most significant within an 800-meter distance among land parcels for general housing and a 400-meter distance for compensational housing, which seem consistent with those of other hedonic price studies specified in major Chinese city contexts (e.g., Wang et al., 2016; Xu \& Zhang, 2016).

\subsection{Transition price models}

The results of the regressions for transaction prices are summarized in Table 2. Columns (1) presents the results of SLM for general housing across urban and suburban areas. After all other effects are controlled for in the regressions, the capitalization effects of proximity to major transportation infrastructure are predicted contrastively. While the distance to nearest highway interchange is insignificant, the distance 
to the closest metro station appears to be negatively associated with the transaction price at the $1 \%$ significance level (elasticity $=-0.1125$ ).

As almost all land parcels are leased out in suburban districts, Columns (2) reports the result of SLM for general housing across suburban areas only. In these regressions, the distance to closest highway interchange also has no effect on transaction prices, but the distance to the closest metro station attains a negative price gradient at the $1 \%$ significance level (elasticity $=-0.1061$ ).

Similarly, the results of SLM for compensational housing are reported in Columns (3)-(4). Remarkably, these regression models show that closest metro station and highway interchange are not significantly related to transaction prices in both urban and suburban areas. However, lease conditions, such as the size of land parcels, FAR and auction type, largely determine land prices for compensational housing along with zone- and time-fixed effects. Note that the price decision mechanism of compensational housing is negotiation-based for public motives, which may not be able to account for the market value of accessibility sufficiently, while that of general housing is competition-based for private profits.

Table 2. Results of SLM regressions for land transaction prices

\begin{tabular}{|c|c|c|c|c|}
\hline & \multicolumn{2}{|c|}{ Land for General Housing-Log(Land_TP) } & \multicolumn{2}{|c|}{ Land for Compensational Housing-log(Land_TP) } \\
\hline & (1)Full Samples & (2)Suburban Samples & (3)Full Samples & (4)Suburban Samples \\
\hline Log(C_Center $)$ & $-0.4201^{* * *}(0.1184)$ & $-0.8804^{* * *}(0.1935)$ & $-0.2672(0.1854)$ & $-0.2196(0.2159)$ \\
\hline Log(L_Size $)$ & $-0.0422^{* *}(0.0218)$ & $-0.0402 *(0.0231)$ & $-0.1083^{* * *}(0.0394)$ & $-0.1127^{* * *}(0.042)$ \\
\hline $\log (\mathrm{FAR})$ & $0.4937^{* * *}(0.0624)$ & $0.5165^{* * *}(0.0661)$ & $1.5731^{* * *}(0.1444)$ & $1.5700^{* * *}(0.1537)$ \\
\hline SOE & $0.0692^{*}(0.0412)$ & $0.0744^{*}(0.0436)$ & $0.0774(0.0566)$ & $0.0894(0.0602)$ \\
\hline Tendering & $-0.8512^{* * *}(0.0959)$ & $-1.0786^{* * *}(0.1146)$ & $-0.5889 *(0.3245)$ & $-0.6136^{*}(0.331)$ \\
\hline Log(D_Center) & $-0.0355(0.04)$ & $-0.0983^{* *}(0.0467)$ & $0.0358(0.067)$ & $0.0831(0.0761)$ \\
\hline $\log (\mathrm{Uni})$ & $-0.0728^{*}(0.0375)$ & $-0.0662(0.0411)$ & $-0.0896(0.0624)$ & $-0.1489^{* *}(0.0734)$ \\
\hline $\log ($ Park $)$ & $-0.0876^{* * *}(0.0193)$ & $-0.0802^{* * *}(0.0203)$ & $0.2452^{* * *}(0.0536)$ & $0.2302^{* * *}(0.057)$ \\
\hline Log(HighW) & $-0.0259(0.0247)$ & $-0.0267(0.0268)$ & $0.0489(0.0391)$ & $0.0490(0.0435)$ \\
\hline Log(Metro) & $-0.1125^{* * *}(0.0243)$ & $-0.1061^{* * *}(0.0249)$ & $-0.0402(0.0382)$ & $-0.0349(0.0399)$ \\
\hline Constant & $15.7927^{* * *}(1.1659)$ & $21.1069^{* * *}(1.9686)$ & $9.6163^{* * *}(1.8498)$ & $9.3303^{* * *}(2.1727)$ \\
\hline Zones & $\mathrm{Y}$ & $\mathrm{Y}$ & $\mathrm{Y}$ & $\mathrm{Y}$ \\
\hline Time & $\mathrm{Y}$ & $\mathrm{Y}$ & $\mathrm{Y}$ & $\mathrm{Y}$ \\
\hline rho & $0.0204^{* * *}(0.0044)$ & $0.0189^{* * *}(0.0047)$ & $0.0147^{* *}(0.0063)$ & $0.0149^{* *}(0.0069)$ \\
\hline Moran's I & $4.5263^{* * *}$ & $4.9247^{* * *}$ & $1.8807^{*}$ & $1.7577^{*}$ \\
\hline Robust LM & $18.3361^{* * *}$ & $13.3124^{* * *}$ & $5.1386^{* *}$ & $4.3841^{* *}$ \\
\hline Lag > Error & $\mathrm{Y}$ & $\mathrm{Y}$ & Y & $\mathrm{Y}$ \\
\hline Observation & 707 & 627 & 381 & 353 \\
\hline
\end{tabular}

Notes: The table shows the results for SLM regressions on the log land transaction price. The numbers in parentheses are standard errors. ${ }^{* * *},{ }^{* *}$, and ${ }^{*}$ denote significance at the $1 \%, 5 \%$, and $10 \%$ levels, respectively.

\subsection{Ask price and bid-ask spread models}

Subsequently, models for ask prices and bid-ask spreads are estimated to measure how premiums for proximity to new metro stations and highway entrances are initially valuated by the district governments 
and how much they are increased by housing developers. These models are applied for general housing only, since the bid-ask spreads equal 1 for compensational housing. As around $10 \%$ of the transactions for general housing have no ask price records, the number of observations is reduced to 640 .

In Table 3, Columns (1)-(2) show the results of SLM for ask prices in all areas and suburban areas respectively, which are similar with those of SLM for transaction prices, as shown in Table 2. Essentially, the distance to nearest highway interchange is assessed as an insignificant determinant, while the distance to nearest metro station has a negative price gradient at the $1 \%$ significance level (elasticity = -0.088 to -0.097 ). One notable difference from the transaction price models is that the SOE dummy is positively associated to ask prices, with a significant level at $1 \%$. It can be presumed that some important land parcels are exclusively assigned to SOEs and their transaction prices are not competitively increased by private developers.

Columns (3)-(4) further show the results of SLM for bid-ask spreads in all areas and suburban areas respectively, in a comparable manner. In short, two of the lease conditions (SOE and auction type) tend to be significant in explaining bid-ask spreads, but all other external attributes, seem to be statistically insignificant.

Table 3. Results of SLM regressions for land ask price and bid-ask spreads for general housing, 2004-2016

\begin{tabular}{|c|c|c|c|c|}
\hline \multirow[t]{2}{*}{ Dependent } & \multicolumn{2}{|l|}{ Log(Land_AskP) } & \multicolumn{2}{|l|}{ Log(Bid-Ask Spread) } \\
\hline & (1)Full Samples & (2)Suburban Samples & (3)Full Samples & (4)Suburban Samples \\
\hline Log(C_Center $)$ & $-0.4275^{* * *}(0.0905)$ & $-0.6465^{* * *}(0.1472)$ & $-0.0203(0.0884)$ & $-0.0852(0.1482)$ \\
\hline Log(L_Size $)$ & $-0.0151(0.017)$ & $-0.0183(0.0179)$ & $-0.0209(0.0166)$ & $-0.0200(0.018)$ \\
\hline $\log (\mathrm{FAR})$ & $0.5732^{* * *}(0.0499)$ & $0.5784^{* * *}(0.0534)$ & $-0.0226(0.0488)$ & $-0.0177(0.0538)$ \\
\hline SOE & $0.1121^{* * *}(0.0305)$ & $0.0993^{* * *}(0.0319)$ & $-0.0558^{*}(0.0297)$ & $-0.0511(0.0321)$ \\
\hline Tendering & $-0.3434^{* * *}(0.1286)$ & $-0.3277^{* *}(0.1359)$ & $-0.3219^{* *}(0.1252)$ & $-0.3481^{* *}(0.1362)$ \\
\hline Log(D_Center) & $-0.0783^{* * *}(0.0302)$ & $-0.1042^{* * *}(0.0353)$ & $0.0411(0.0291)$ & $0.0278(0.0349)$ \\
\hline $\log (\mathrm{Uni})$ & $-0.0973^{* * *}(0.0285)$ & $-0.1122^{* * *}(0.0314)$ & $0.0212(0.0278)$ & $0.0289(0.0314)$ \\
\hline $\log ($ Park $)$ & $-0.0862^{* * *}(0.0146)$ & $-0.0815^{* * *}(0.0155)$ & $-0.0025(0.0143)$ & $0.0006(0.0156)$ \\
\hline $\log ($ HighW $)$ & $-0.0090(0.0191)$ & $-0.0188(0.0206)$ & $-0.0015(0.0186)$ & $-0.0011(0.0207)$ \\
\hline Log(Metro) & $-0.0974^{* * *}(0.0183)$ & $-0.0884^{* * *}(0.0188)$ & $-0.0163(0.0178)$ & $-0.0201(0.0188)$ \\
\hline Constant & $17.1991^{* * *}(0.9009)$ & $19.8293^{* * *}(1.4935)$ & $0.6726(0.8768)$ & $1.3798(1.4987)$ \\
\hline Zones & $\mathrm{Y}$ & $\mathrm{Y}$ & $\mathrm{Y}$ & $\mathrm{Y}$ \\
\hline Time & $\mathrm{Y}$ & Y & $\mathrm{Y}$ & $\mathrm{Y}$ \\
\hline rho & $0.0126^{* * *}(0.0035)$ & $0.012^{* * *}(0.0037)$ & $0.1564^{* * *}(0.0329)$ & $0.1588^{* * *}(0.0343)$ \\
\hline Moran's I & $4.8167^{* * *}$ & $4.8155^{* * *}$ & $4.3327^{* * *}$ & $4.1888^{* * *}$ \\
\hline Robust LM & $11.397^{* * *}$ & $16.442^{* * *}$ & $12.1843^{* * *}$ & $12.9877^{* * *}$ \\
\hline Lag $>$ Error & $\mathrm{Y}$ & Y & $\mathrm{Y}$ & $\mathrm{Y}$ \\
\hline Observation & 640 & 575 & 640 & 575 \\
\hline
\end{tabular}

Notes: The dependent variable is the log ask price of land parcels for columns (1)-(2), and the log bid-ask spread of land parcels for columns (3)-(4). The numbers in parentheses are standard errors. ${ }^{* * *},{ }^{* *}$, and ${ }^{*}$ denote significance at the $1 \%, 5 \%$, and $10 \%$ levels, respectively. 


\subsection{Transaction price, ask price, and bid-ask spreads with time effect models}

Generally, the capitalization effects of transportation investment on property sales or rents under freehold systems are serially observed in different stages of a project, such as announcement, construction, and opening effects (e.g., Zheng \& Kahn, 2013), which are likely to occur on the intermediate land market under Shanghai's leasehold system. Specifically, temporal effects of the metro extensions are tested in regressions for transaction prices, ask prices, and bid-ask spreads using year leads and lags, which could partially mitigate the issue of causality between transportation infrastructure investments and housing price formation.

Figure 3 illustrates the temporal distribution of residential land transactions within $1 \mathrm{~km}$ of new metro stations. The distribution of transactions for compensational housing is right-skewed, as a large majority of land parcels are leased out for compensational housing after the opening of metro stations. Conversely, the distribution of transactions for general housing appears to follow a normal distribution around the opening of metro stations, although nearly $25 \%$ of the land parcels for general housing were leased out during 1-2 years before new metro services became operational. As developers are generally required to develop land parcels within two years of the auction date, transfers of land-use rights from district governments seem to be proactively arranged around new stations in some years earlier.

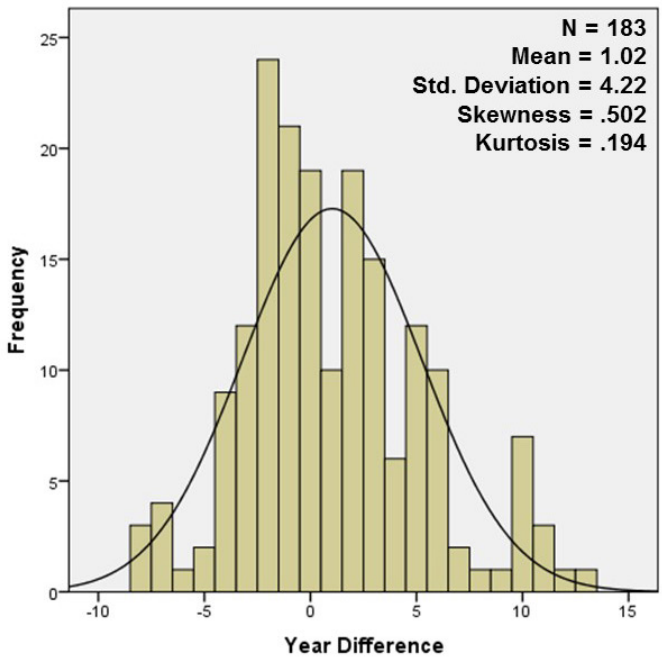

(a) General

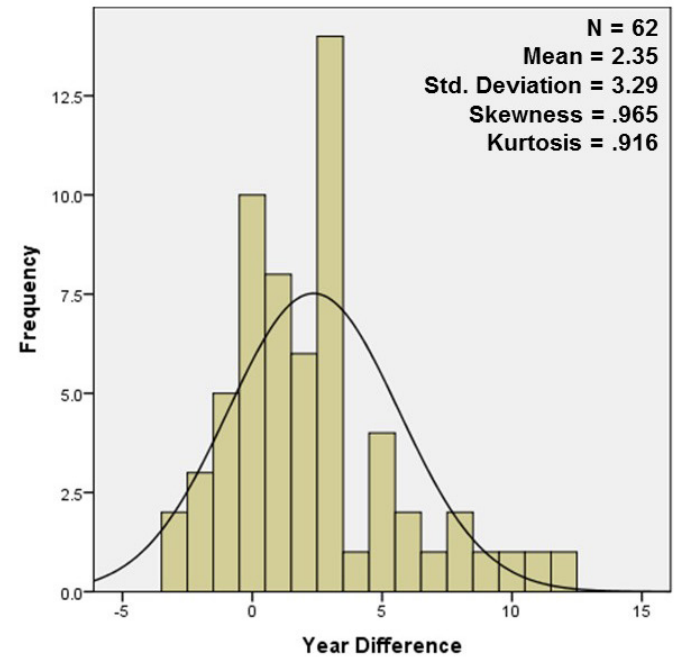

(b) Compensational

Figure 3. Year lead/lag distribution of land transactions within $1 \mathrm{~km}$ of metro stations

Table 4 summarizes the temporal effects of metro extensions on transaction prices, ask prices, and bid-ask spreads estimated within $1 \mathrm{~km}$ of new stations, controlling for the influences of lease conditions and local public goods along with sub-district and year fixed effects. Column (1) shows that transaction prices within $1 \mathrm{~km}$ of new metro stations are significantly higher than those beyond $1 \mathrm{~km}$, especially with metro year lag1 and lag2 (premium $=+28.68 \%$ and $+29.01 \%$, respectively). Column (2) also indicates that ask prices within $1 \mathrm{~km}$ of new metro stations tend to be high, although the magnitude is lower than transaction prices. However, Column (3) further reports that year lead effects are insignificant in explaining bid-ask spreads, as developers are unwilling to pay extra premiums for land parcels around existing metro stations. Conversely, year lag effects are significantly positive since developers tend to proactively (or even speculatively) bid for land parcels within $1 \mathrm{~km}$ of forthcoming metro stations, especially with year lag1 and lag2 (additional premium $=+14.41 \%$ and $+11.89 \%$, respectively). Finally, 
Column (4) reconfirms insignificant price premiums for compensational housing around metro stations regardless of year leads and lags.

Table 4. Results of SLM regressions with time effect for land parcels located within a $1 \mathrm{~km}$ catchment area of metro stations

\begin{tabular}{lllll}
\hline & \multicolumn{3}{l}{ General Residential Land } & Compensational Land \\
\cline { 2 - 5 } & $(1) \log \left(\operatorname{Land} \_T P\right)$ & $(2) \log \left(\operatorname{Land} \_\right.$AskP $)$ & $(3) \log ($ Bid-Ask Spread $)$ & $(4) \log (\operatorname{Land}$ _TP $)$ \\
\hline D_MLead4 & $0.2046^{* *}(0.0873)$ & $0.2025^{* * *}(0.0657)$ & $-0.0389(0.0633)$ & $0.2291^{*}(0.1291)$ \\
D_MLead3 & $0.2471^{* * *}(0.0775)$ & $0.1700^{* * *}(0.0582)$ & $0.0311(0.056)$ & $0.0019(0.0917)$ \\
D_MLead2 & $0.2068^{* * *}(0.0667)$ & $0.1650^{* * *}(0.0501)$ & $0.0161(0.0484)$ & $-0.0280(0.0825)$ \\
D_MLead1 & $0.2060^{* * *}(0.0623)$ & $0.1740^{* * *}(0.0483)$ & $0.0039(0.0467)$ & $-0.0629(0.0765)$ \\
D_Metro & $0.2730^{* * *}(0.0575)$ & $0.1440^{* * *}(0.0446)$ & $0.0948^{* *}(0.0429)$ & $0.0157(0.0733)$ \\
D_MLag1 & $0.2868^{* * *}(0.0542)$ & $0.1110^{* * *}(0.0425)$ & $0.1441^{* * *}(0.0406)$ & $0.0326(0.0708)$ \\
D_MLag2 & $0.2901^{* * *}(0.0503)$ & $0.1383^{* * *}(0.0404)$ & $0.1189^{* * *}(0.0389)$ & $0.0308(0.0712)$ \\
D_MLag3 & $0.2243^{* * *}(0.049)$ & $0.1102^{* * *}(0.0389)$ & $0.0841^{* *}(0.0374)$ & $0.0238(0.0686)$ \\
D_MLag4 & $0.2400^{* * *}(0.0478)$ & $0.1402^{* * *}(0.0378)$ & $0.0715^{*}(0.0365)$ & $0.0013(0.0676)$ \\
& & & & \\
Log(C_Center) & $Y$ & $Y$ & $Y$ & $\mathrm{Y}$ \\
Land Attributes & $\mathrm{Y}$ & $\mathrm{Y}$ & $\mathrm{Y}$ & $\mathrm{Y}$ \\
Public Good & $\mathrm{Y}$ & $\mathrm{Y}$ & $\mathrm{Y}$ & $\mathrm{Y}$ \\
Log(HighW) & $\mathrm{Y}$ & $\mathrm{Y}$ & $\mathrm{Y}$ & $\mathrm{Y}$ \\
& & $\mathrm{Y}$ & $\mathrm{Y}$ & $\mathrm{Y}$ \\
Zones & $\mathrm{Y}$ & $\mathrm{Y}$ & $\mathrm{Y}$ & $\mathrm{Y}$ \\
Time & $\mathrm{Y}$ & $\mathrm{Y}$ & $\mathrm{Y}$ & $\mathrm{Y}$ \\
LM Test & $\mathrm{Y}$ & 640 & 640 & 381 \\
\hline Observation & 707 & & & \\
\hline
\end{tabular}

Notes: The table shows the results on the effect of metro stations on land price within a 1-km catchment area of metro stations. Columns (1)-(3) measures this lead/lag time effect for the log transaction price, log ask price and bid-ask spreads of residential land for general housing. Column (4) measures the lead/lag time effect for the log transaction price of land for compensational housing. Land attributes include log size of land parcels, FAR, SOE (dummy), tendering (dummy). The public good includes the distance of land parcels to district government center, universities, and parks. The numbers in parentheses are standard errors. ${ }^{* *},{ }^{* *}$, and ${ }^{*}$ denote significance at the $1 \%, 5 \%$, and $10 \%$ levels, respectively.

\section{$5 \quad$ Conclusions}

This study contributes to grasping the association of government land dispositions with transportation infrastructure extensions for the efficiency and sustainability of human settlements in emerging economies by an in-depth investigation of spatiotemporal price formation for long-term land-use rights regarding the successive expansions of metro and highway networks in Shanghai, China. The empirical results imply that the accessibility benefits of metro extensions are substantially capitalized into both the ask and transaction prices of land-use rights for general housing development in suburban districts, whereas the capitalization effects of highway constructions are insignificant. This price formation suggests that both state-led spatial strategies and market-driven development initiatives have progressively been directing Shanghai's residential suburbanization as transit-oriented rather than car-dependent over the past decade.

However, the results also demonstrate that the premiums for proximity to new metro stations bid by developers appear to be much higher than those asked by district governments, especially within two 
years before new train services come into operation. The high premiums raised by developers during pre-metro years are likely to indicate speculative investments in Shanghai's upward suburban housing market (which can be different from the "net" impacts of metro extensions), whereas the prices of land-use rights for general housing asked by district governments are inaccurately pre-assessed without accounting for "construction" effects or intentionally discounted to promote proactive housing development on strategically selected sites around new metro stations. In addition, this analysis reveals the fact that the prices of land-use rights for compensational housing do not reflect any economic externalities (or true market values) attributable to metro stations, highway interchanges, and other local public goods, which might further worsen uneven and unfair redistribution of property rights, accessibility to social opportunities, and, in turn, economic wealth among relocated farmers within and across Shanghai's suburban districts.

These empirical findings lend credence to the accumulating evidence that China's successive metro extensions could play a pivotal role in guiding human settlement patterns via metropolitan-wide accessibility changes and curbing suburban sprawl using transit-supportive land-use arrangements and travel demand management techniques. While many hedonic price studies in China have built on Western literature on end-consumer' transit-oriented housing preferences under market freehold systems, this study claims that the price formation of long-term land-use rights between local governments and private developers must be spatiotemporally analyzed considering the provision of major transportation infrastructure and thoughtfully projected as a critical path of transit-oriented land management and local capital improvement programs under state leasehold systems. Particularly, some policy measures for housing affordability and social inclusiveness need to be incorporated into the current TOD programs (or the TOD principles should be applied to the current compensational housing scheme). The policy implications drawn from the case of Shanghai are not limited to major cities in China but rather apply to several emerging megacities across the developing world, currently under similar state leasehold systems or that attempt to develop the administrative capacity to implement complex land management programs and deliver major transportation infrastructure projects regarding rapid suburbanization.

In summary, this paper highlights five analytical challenges for future research. First, it focuses on residential land only, since the nature of commercial and industrial land appears to be fundamentally different as per our preliminary analyses and findings (Murakami \& Chang, 2018). Grasping the distinctive characteristics of non-residential land transactions associated with local economic policies is scope for further research. Second, small cities with insufficient administrative capacity and market potential are beyond the scope of this case study. The methodology applied here should be adapted to assess small cities' leasehold administration practices with local-specific policy considerations and feasible land management techniques. Third, the key contribution of this study is its empirical findings, while Chinass leasehold administration and municipal finance are highly political subjects. As such, follow-up qualitative research could further expose pragmatic implementations. Fourth, this research identifies the transfers of long-term land-use rights from initial land suppliers to intermediate land consumers as a critical path, but there remains the question of how the intermediate transactions would affect the formation of end-consumer markets around metro stations and highway interchanges. Comparative studies on land-use rights, property sales, and housing rents should be conducted for sequential periods in the same geographic area. Finally, the transit-oriented spatial strategies and market initiatives directed through intermediate transactions of land-use rights could not effectively meet environmental and socioeconomic targets, if the high-priced housing properties built up around new metro stations were kept vacant for speculative purposes in end-consumer markets. As such, it is crucial to scrutinize the extensive influences of residential land transactions with respect to metro stations and highway interchanges on travel behavior alterations and key environmental/socioeconomic indicators via truly accessible and sustainable human settlements in the coming years. 


\section{Acknowledgements}

The work described in this paper was funded by City University of Hong Kong Strategic Research Grant (Project No.7004376, "Residential Land-Use Pattern in Shanghai and Selected Chinese Metropolises"). The authors thank for the valuable comments from the research seminar hosted by the Department of Urban Planning and Design at the University of Hong Kong and XIth World Conference of the Spatial Econometrics Association hosted by the Singapore Management University. Ms. Cheng, Jing provided excellent research assistance in the data collection and preliminary interview surveys at City University of Hong Kong. 


\section{References}

Alonso, W. (1964). Location and land use. Cambridge, MA: Harvard University Press.

Cervero, R. (2013). Linking urban transport and land use in developing countries. Journal of Transport and Land Use, 6(1), 7-24. doi:10.5198/jtlu.v1.425

Cai, H., Henderson, J. V., \& Zhang, Q. (2013). China's land market auctions: Evidence of corruption. The RAND Journal of Economics, 44(3), 488-521. doi:10.1111/1756-2171.12028

Cervero, R., \& Day, J. (2008). Suburbanization and transit-oriented development in China. Transport Policy, 15(5), 315-323. doi:10.1016/j.tranpol.2008.12.011

Chang, Z. (2014). Financing new metros-The Beijing metro financing sustainability study. Transport Policy, 32, 148-155. doi:10.1016/j.tranpol.2014.01.009

Chang, Z. (2013). Public-private partnerships in China: A case of the Beijing No. 4 Metro line. Transport Policy, 30, 153-160. doi:10.1016/j.tranpol.2013.09.011

Chang, Z., \& Phang, S. Y. (2017). Urban rail transit PPPs: Lessons from East Asian cities. Transportation Research Part A: Policy and Practice, 105, 106-122. doi:10.1016/j.tra.2017.08.015

Chen, X., \& Zhao, J. (2013). Bidding to drive: Car license auction policy in Shanghai and its public acceptance. Transport Policy, 27, 39-52. doi:10.1016/j.tranpol.2012.11.016

Day, J., \& Cervero, R. (2010). Effects of residential relocation on household and commuting expenditures in Shanghai, China. International Journal of Urban and Regional Research, 34(4), 762-788. doi:10.1111/j.1468-2427.2010.00916.x

Ding, C. (2007). Policy and praxis of land acquisition in China. Land Use Policy, 24(1), 1-13. doi:10.1016/j.landusepol.2005.09.002

Ding, C. (2003). Land policy reform in China: Assessment and prospects. Land Use Policy, 20(2),109120. doi:10.1016/S0264-8377(02)00073-X

Drukker, D. M., Prucha, I. R., \& Raciborski, R. (2011). A command for estimating spatial autoregressive models with spatial-autoregressive disturbances and additional endogenous variables. The Stata Journal, 13(2), 287-301.

Gakenheimer, R. (1999). Urban mobility in the developing world. Transportation Research Part A: Policy and Practice, 33(7), 671-689. doi:10.1016/S0965-8564(99)00005-1

Gaubatz, P. (1999). China's urban transformation: Patterns and processes of morphological change in Beijing, Shanghai and Guangzhou. Urban Studies, 36(9), 1495-1521. doi:10.1080/0042098992890

Han, S. (2000). Shanghai between state and market in urban transformation. Urban Studies, 37(11), 2091-2112. doi:10.1080/713707226

He, S., Liu, Y., Webster, C., \& Wu, F. (2009). Property rights redistribution, entitlement failure and the impoverishment of landless farmers in China. Urban Studies, 46(9), 1925-1949. doi:10.1177/0042098009106015

Huang, H., \& Yin, L. (2015). Creating sustainable urban built environments: An application of hedonic house price models in Wuhan, China. Journal of Housing and the Built Environment, 30(2), 219-235. doi:10.1007/s10901-014-9403-8

Kenworthy, J., \& Hu, G. (2002). Transport and urban form in Chinese cities: An international comparative and policy perspective with implications for sustainable urban transport in China. disP-The Planning Review, 38(151), 4-14. doi:10.1080/02513625.2002.10556818

Kenworthy, J., \& Townsend, C. (2002). An international comparative perspective on motorization in urban China: Problems and prospects. IATSS Research, 26(2), 99-109. doi:10.1016/S03861112(14)60049-2

Lichtenberg, E., \& Ding, C. (2008). Assessing farmland protection policy in China. Land Use Policy, 25(1), 59-68. doi:10.1016/j.landusepol.2006.01.005 
Loo, B.P, \& Li, D.Y. (2006). Developing metro systems in the People's Republic of China: Policy and gaps. Transportation, 33(2), 115-132. doi:10.1007/s11116-005-3046-2

Lyu, G., Bertolini, L., \& Pfeffer, K. (2016). Developing a TOD typology for Beijing metro station areas. Journal of Transport Geography, 55, 40-50. doi:10.1016/j.jtrangeo.2016.07.002

Ma, M., Lu, Z., \& Sun, Y. (2008). Population growth, urban sprawl and landscape integrity of Beijing City. The International Journal of Sustainable Development \& World Ecology, 15(4), 326-330. doi:10.3843/SusDev.15.4:6a

Man, J. Y. (2012). China's property tax reform: Progress and challenge Retrieved from http://www.lincolninst.edu/publications/articles/chinas-property-tax-reform

Martin, G. (2007). Global motorization, social ecology and China. Area, 39(1), 66-73. doi: 10.1111/j.1475-4762.2007.00718.x

Mills, E. S. (1972). Studies in the structure of the urban economy. Baltimore, MD: The Johns Hopkins Press.

Murakami, J., \& Chang, Z. (2018). Polycentric development under public leasehold: A spatial analysis of commercial land-use rights. Regional Science and Urban Economics, 71, 25-36. doi:10.1016/j. regsciurbeco.2018.05.001

Muth, R.F. (1964). The derived demand curve for a productive factor and the industry supply curve. Oxford Economic Papers, 16(2), 221-234. Retrieved from https://www.jstor.org/stable/2662270

Pan, H., Shen, Q., \& Liu, C. (2011). Transit-oriented development at the urban periphery: Insights from a case study in Shanghai, China. Transportation Research Record: Journal of the Transportation Research Board, 2245, 95-102. doi:10.3141/2245-12

Pan, H., Shen, Q., \& Zhang, M. (2009). Influence of urban form on travel behavior in four neighborhoods of Shanghai. Urban Studies, 46(2), 275-294. doi:10.1177/0042098008099355

Pan, H., \& Zhang, M. (2008). Rail transit impacts on land use: Evidence from Shanghai, China. Transportation Research Record: Journal of the Transportation Research Board, 2048, 16-25. doi:10.3141/204803

Pucher, J., Peng, Z., Mittal, N., Zhu, Y., \& Korattyswaroopam, N. (2007). Urban transport trends and policies in China and India: Impacts of rapid economic growth. Transport Reviews, 27(4), 379-410. doi:10.1080/01441640601089988

Rosen, S. (1974). Hedonic prices and implicit markets: Product differentiation in pure competition. Journal of Political Economy, 82 (1), 34-55.

Seto, K.C., Dhakal, S., Bigio, A., Huang, L, Inaba, A., Kansal, A.,... Ramaswami, A. (2014). Chapter 12 - Human settlements, infrastructure and spatial planning. In O. Edenhofer, R. Pichs-Madruga, Y. Sokona, E. Farahani, S. Kadner, K. Seyboth,... J.C. Minx (Eds.), Climate change 2014: Mitigation of climate change (pp.923-1000). Cambridge, UK: Cambridge University Press.

Shanghai Municipal People's Government. (2011). The approval for the Shanghai's housing bureau's regulations on compensational housing in Shanghai. Retrieved from http://www.shanghai.gov.cn/ nw2/nw2314/nw2319/nw2404/nw26344/nw26345/u26aw28429.html

Shanghai Municipal People's Government. (2009). Policies on promoting the urban redevelopment of Shanghai government. Retrieved from http://www.shanghai.gov.cn/nw2/nw2314/nw2319/ nw11494/nw12331/nw12343/nw22595/u26aw17516.html

Shanghai Statistical Bureau. (2016). Shanghai statistical yearbook 2016. Beijing: China Statistics Press. Shen, Q. (1997). Urban transportation in Shanghai, China: Problems and planning implications. International Journal of Urban and Regional Research, 21(4), 589-606. doi:10.1111/1468-2427.00103

Shen, L., Jiao, L., He, B., \& Li, L. (2015). Evaluation on the utility efficiency of metro infrastructure projects in China from sustainable development perspective. International Journal of Project Management, 33(3), 528-536. doi:10.1016/j.ijproman.2014.07.005 
Suzuki, H., Cervero, R., \& Iuchi, K. (2013). Transforming cities with transit: Transit and land-use integration for sustainable urban development. Washington, DC: The World Bank.

Suzuki, H., Murakami, J., Hong, Y., \& Tamayose, B. (2015). Financing transit-oriented development with land values: Adapting land value capture in developing countries. Washington, DC: The World Bank.

Tian, L. (2006). Impacts of transport projects on residential property values in China: Evidence from two projects in Guangzhou. Journal of Property Research, 23(4), 347-365. doi:10.1080/09599910601095365

Tian, L., \& Ma, W. (2009). Government intervention in city development of China: A tool of land supply. Land Use Policy, 26(3), 599-609. doi: 10.1016/j.landusepol.2008.08.012

Tiebout, C. (1956). A pure theory of local expenditures. Journal of Political Economy, 64, 416-424.

United Nations. (2014). 2014 Revision of world urbanization prospects. Retrieved from https:/esa. un.org/unpd/wup/

UN-Habitat. (2011). Cities and climate change: Global report on human settlements 2011. Nairobi: United Nations Human Settlements Program, Earthscan.

Wang, Y., Feng, S., Deng, Z., \& Cheng, S. (2016). Transit premium and rent segmentation: A spatial quantile hedonic analysis of Shanghai Metro. Transport Policy, 51, 61-69. doi:10.1016/j.tranpol.2016.04.016

Wang, L., Kundu, R., \& Chen, X. (2010). Building for what and whom? New town development as planned suburbanization in China and India. In M. Clapson \& R. Hutchison (Eds.), Suburbanization in Global Society (pp. 319-345). Bingley, UK: Emerald Group Publishing Limited.

Wilson, J., \& Wildasin, D. (2004). Capital tax competition: Bane or boon. Journal of Public Economics, 88, 1065-1091. doi:10.1016/S0047-2727(03)00057-4

Xie, Q., Parsa, A. G., \& Redding, B. (2002). The emergence of the urban land market in China: Evolution, structure, constraints and perspectives. Urban Studies, 39(8), 1375-1398. doi:10.1080/00420980220142682

Xu, J., Yeh, A., \& Wu, F. (2009). Land commodification: New land development and politics in China since the late 1990s. International Journal of Urban and Regional Research, 33(4), 890-913. doi:10.1111/j.1468-2427.2009.00892.x

Xu, T., \& Zhang, M. (2016). Tailoring empirical research on transit access premiums for planning applications. Transport Policy, 51, 49-60. doi:10.1016/j.tranpol.2016.03.003

Xu, T., Zhang, M., \& Aditjandra, P. T. (2016). The impact of urban rail transit on commercial property value: New evidence from Wuhan, China. Transportation Research Part A: Policy and Practice, 91, 223-235. doi:10.1016/j.tra.2016.06.026

Yan, X., \& Crookes, R. J. (2010). Energy demand and emissions from road transportation vehicles in China. Progress in Energy and Combustion Science, 36(6), 651-676. doi:10.1016/j.pecs.2010.02.003

Yang, J., Chen, J., Le, X., \& Zhang, Q. (2016). Density-oriented versus development-oriented transit investment: Decoding metro station location selection in Shenzhen. Transport Policy, 51, 93-102. doi: 10.1016/j.tranpol.2016.04.004

Yang, J., Quan, J., Yan, B., \& He, C. (2016). Urban rail investment and transit-oriented development in Beijing: Can it reach a higher potential? Transportation Research Part A: Policy and Practice, 89, 140-150. doi:10.1016/j.tra.2016.05.008

Zhang, M. (2007). Chinese edition of transit-oriented development. Transportation Research Record: Journal of the Transportation Research Board, 2038, 120-127. doi:10.3141/2038-16

Zhang, M., Meng, X., Wang, L., \& Xu, T. (2014). Transit development shaping urbanization: Evidence from the housing market in Beijing. Habitat International, 44, 545-554. doi:10.1016/j.habitatint.2014.10.012 
Zhang, M., \& Wang, L. (2013). The impacts of mass transit on land development in China: The case of Beijing. Research in Transportation Economics, 4O(1), 124-133. doi:10.1016/j.retrec.2012.06.039

Zhang, T. (2000). Land market forces and government's role in sprawl: The case of China. Cities, 17(2), 123-135. doi:10.1016/S0264-2751(00)00007-X

Zhang, Y. (2012). Institutional sources of reform: The diffusion of land banking systems in China. Management and Organization Review, 8(3), 507-533. doi:10.1111/j.1740-8784.2011.00256.x

Zhao, P. (2010). Sustainable urban expansion and transportation in a growing megacity: Consequences of urban sprawl for mobility on the urban fringe of Beijing. Habitat International, 34(2), 236-243. doi:10.1016/j.habitatint.2009.09.008

Zhao, P., Lü, B., \& de Roo, G. (2010). Urban expansion and transportation: The impact of urban form on commuting patterns on the city fringe of Beijing. Environment and Planning A, 42(10), 2467-2486. doi:10.1068/a4350

Zheng, S., \& Kahn, M. E. (2008). Land and residential property markets in a booming economy: New evidence from Beijing. Journal of Urban Economics, 63(2), 743-757. doi:10.1016/j.jue.2007.04.010

Zheng, S., \& Kahn, M. E. (2013). Does government investment in local public goods spur gentrification? Evidence from Beijing. Real Estate Economics, 41(1), 1-28. doi:10.1111/j.1540-6229.2012.00339.x

Zhou, Y., \& Ma, L. J. (2000). Economic restructuring and suburbanization in China. Urban Geography, 21(3), 205-236. doi:10.2747/0272-3638.21.3.205

Zhu, J. (2002). Urban development under ambiguous property rights: A case of China's transition economy. International Journal of Urban and Regional Research, 26(1), 41-57. doi:10.1111/14682427.00362 